\title{
Athaliah and Alexandra: Gender and Queenship in Josephus
}

Athaliah and Alexandra were the only two women to rule as queens of Judah/Judaea in their own right and both women's reigns are reported in Josephus' writings. Despite their uniqueness, however, Athaliah and Alexandra are rarely compared in scholarship; the former is usually dismissed, and focus centred on the latter. This paper, however, contends that are historical similarities between the two, but literary differences. Josephus could have referred to Athaliah or used elements of her portrayal in his presentation of Alexandra but does not, creating the impression that Alexandra was completely different to her predecessor. It may be instructive, therefore, to consider why Josephus literarily isolates the queens and what this means for his interpretation of Alexandra.

Keywords: Athaliah - Alexandra Salome - Queens in Josephus - Hasmoneans

\section{Introduction}

Numerous studies focus on the topic of women in Josephus and, in recent years, Queen Shelamzion/Salome Alexandra (reigned c. 76-67 BCE) and other royal Hasmonean and Hellenistic women have also received scholarly attention. ${ }^{1}$ Although a number of women ruled as co-regents in antiquity, the uniqueness of Alexandra among them is often emphasised as she ruled as sovereign in her own right over Judaea. ${ }^{2}$ Alexandra was not, however, the only woman to rule ancient Judah/Judaea, as Athaliah ruled for six years in the ninth century BCE (c. 841-835). ${ }^{3}$ The main sources for Alexandra's reign are Josephus' War (1.107-119) and Antiquities (13.403-432), the latter of which also reports a version of Athaliah's reign (Ant.9.140-156). ${ }^{4}$ Yet, these two queens are rarely discussed together despite scholarly observations of similarities or typologies in Josephus' portrayals of other prominent women. ${ }^{5}$ This study contends that there were historical and political similarities

\footnotetext{
* We are grateful to Ellena Lyell for her assistance in editing the manuscript and to the reviewer for their helpful comments.

${ }^{1}$ We refer to Queen Shelamzion/Salome Alexandra as Alexandra hereafter. See further literature in, for example, Ilan, Silencing the Queen; Ilan, "Flavius Josephus," 167-185; Ilan, "Josephus and Nicholaus," 221262; Ilan, "Josephus on Women," 210-221; Halpern-Amaru, "Portraits," 143-170; Liebowitz, "Ambivalent Attitude," 182-205; Baltrusch, "Königin Salome Alexandra," 163-179; Lambers-Petry, "Shelomzion hamalka," 63-77; Feldman, "Hellenizations," 143-170; Swart, "Rahab and Esther," 50-65.

${ }^{2}$ See especially Liebowitz, "Female Monarchal Succession," 30-48.

${ }^{3} 2$ Kings 11:1-20//2 Chr 22:10-23:21.

${ }^{4}$ The translations of Josephus used herein are from Ralph Marcus [LCL 365] and H. St. J. Thackeray [LCL 203] unless otherwise noted.

${ }^{5}$ Many works on Alexandra simply do not mention Athaliah and those that do are typically brief. Thus, for example, Ilan (Silencing the Queen) affords Athaliah three pages of discussion (44-46) as a preface to her chapter on Alexandra (47-60) but she does not connect the two figures beyond observations that they both ruled as legitimate monarchs. Similarly, Liebowitz mentions Athaliah only in passing, noting that Josephus used the same term $(\beta \alpha \sigma i \lambda \varepsilon v ́ \omega)$ to describe both Athaliah and Alexandra's reigns; Liebowitz, "Ambivalent Attitude," 192. Although Halpern-Amaru discusses numerous biblical women in her identification of five female
} 
between the two women and their reigns, but that Josephus avoids making any literary connection between the two, so that the polemic against Athaliah would not negatively affect the reception of Alexandra. In this regard, our contention of authorial intent contrasts with those who view Athaliah as automatically illegitimate and therefore irrelevant as a point of comparison. Thus, for example, Joseph Sievers dismisses any potential comparison by stating that Athaliah, "was not Judean, was a devotee of Ba'al, and was notorious for seizing the throne upon the death of her son by destroying almost the entire royal family (2 Kgs 11:1-3). Evidently, she did not serve as a model for the Hasmoneans." Although strongly influenced by his acceptance of the biblical polemic, Sievers is correct in his final analysis; Athaliah did not serve as a model for the Hasmoneans, but, importantly, Josephus also did not connect the two women. What this paper seeks to explore, however, is why this is the case when other biblical women in Josephus' works evince comparative elements. ${ }^{7}$ The following thus discusses similar aspects of Athaliah and Alexandra's reigns and their portrayal in Josephus, in particular, their respective rises to power, the presentation of their reigns and administrations, and the reports of eventual coups against them. We conclude that there were significant similarities between the two queens and their reigns, which Josephus avoids making explicit. This desire for difference may also underlie some of his additions to the biblical narratives in his own version of Athaliah's reign. ${ }^{8}$

\section{From Consort to Queen: Women Rising to Power}

Both Athaliah and Alexandra were consorts to the reigning king with grown sons who were heirs to the throne. Athaliah's son Ahaziah became king when his father, king Joram, died but he ruled for only one year prior ( $2 \mathrm{Kgs} 8: 24-26$ ) to his untimely death during Jehu's coup against the northern kingdom ( $2 \mathrm{Kgs}$ 9:27-28). In the resulting chaos, Athaliah - once royal consort, once queen-mother - became queen of Judah. It is unclear whether Athaliah was queen-regent, perhaps ruling on behalf of Ahaziah's baby son Joash, or whether she was queen in her own right. ${ }^{9}$ If she was ruling on Joash's behalf, his infancy would have

\footnotetext{
typologies in Josephus' work, Athaliah is only briefly mentioned as a potential villainess ("Portraits," 165-166). Even there, Halpern-Amaru admits that Athaliah does not fit any of her categories, which she attributes to the lack of character development of her husband, rather than anything to do with Athaliah herself.

${ }^{6}$ Sievers, "Role of Women," 134.

${ }^{7}$ For instance, Esther has more connections with Alexandra in Josephus' work than Athaliah, despite Esther being a consort and Athaliah being the only other female monarch in biblical history. See Liebowitz, "Esther and Alexandra"; Liebowitz, "Ambivalent Attitude," 197-199. The question is further heightened when one considers two texts from Qumran which are proposed to polemically associate Alexandra with negative biblical portrayals of royal or prominent women, pesharim on Nahum and Hosea (4Q169; 4Q166); see Ilan,

"Shelamzion in Qumran," 57-68; Silencing the Queen, 61-72. Here too, it is interesting that Athaliah does not appear as a comparative model, though it must also be noted that only a few sections of 1-2 Kgs were found at Qumran (4Q54; 4Q382; 4Q481a; 5Q2; 6Q4), none of which include $2 \mathrm{Kgs} \mathrm{11,} \mathrm{and} \mathrm{conclusions} \mathrm{are} \mathrm{therefore}$ difficult to draw.

${ }^{8}$ We will return to this issue below, but for extended discussion see Quine and Scales, "Josephus' Adaptation." ${ }^{9}$ Sergi, "Queenship," 105-109 argues that it is likely Athaliah was serving as queen-regent for a young male heir, which makes the biblical account of her slaughter of 'all the royal seed' unlikely, though it is not impossible that she was involved in a power-struggle. Joash's origins, meanwhile, are unfortunately unclear; 2 Kgs 11:2 states that he was Ahaziah's son, but 2 Kgs 12:1-2 MT (and most versions) do not name his father in
} 
effectively rendered her the sole ruler, though we cannot rule out that she was, in fact, the sole ruler, or that she was co-regent for another unnamed heir whom Joash replaced in Jehoiada's coup. Either way, there seems to have been a shortage of appropriate male heirs and thus Athaliah's rise to power was very different to Alexandra's. ${ }^{10}$ While ninth-century Judah seemingly experienced a dynastic crisis, Alexander Jannaeus (Jannaeus hereafter) had two potentially appropriate male heirs available to succeed him, whom Alexandra replaced.

Alexandra first appears in Josephus' War where Jannaeus bequeathed ( $x \alpha \tau \alpha \lambda \varepsilon i ́ \tau \varepsilon \iota)$ her the kingdom ( $\beta \alpha \sigma \iota \lambda \varepsilon i ́ \alpha v)$ on his deathbed (War 1.107) as Alexandra was popular and had a

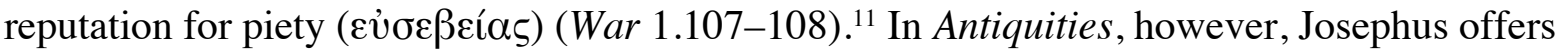
an expanded version which is not unlike the scene between David and Bathsheba in $1 \mathrm{Kgs} 1$, wherein the king is ill and only his wife (and the omniscient narrator) are present to hear him bequeath the throne to a particular successor. Interestingly, Bathsheba and Alexandra both appeal to the kings on account of their and their children's safety; Bathsheba fears that she and Solomon will be counted as offenders once David dies (והייתי אני ובני שלמה חטאים, 1 Kgs 1:21) and Alexandra states that she and her children ( $\tau \dot{\varepsilon} x v \alpha$ ) are in danger. Bathsheba's claim has some basis, as we are told that Adonijah had already launched a bid for David's throne (1 Kgs 1:5-10). Alexandra's statement, however, is intriguing, as no other threats are reported and her "children" were both seemingly grown men. Despite her initiative, however, Josephus is careful to present Jannaeus as the creator of the plan to put Alexandra on the throne. ${ }^{12}$ It is Jannaeus who tells Alexandra to conceal his death until she is in power (Ant. 13.400), and he who tells her to offer the Pharisees a measure of influence to win over hostile

his formal ascension notice. As Bench, Coup of Jehoiada, 88-95 notes, however, the Lucianic version offers an important deviation from these omissions, stating "in the seventh year of Jehu, Jehoash, son of Ahaziah began to reign." Evidently, Joash's parentage was uncertain, but if Joash was Ahaziah's son, then it is likely the omission of Ahaziah's name in his ascension notice(s) was for ideological reasons, because the authors wished to distance Joash from his part-Israelite/Omride heritage. Slightly differently, Mullen Jr. notes that while she may have served as regent, Athaliah may also have taken the throne legitimately in the absence of a Davidic heir and Joash may not have been of the Davidic line but instead started a new dynasty via Jehoiada's coup; Mullen Jr., Narrative History, 29-31. For discussion and further literature see - amongst others - Brewer-Boydston, Good Queen Mothers, 114-117.

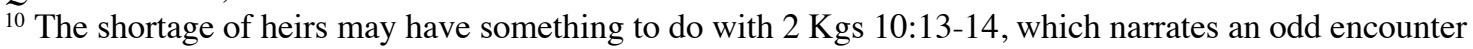
wherein Jehu slaughtered forty-two "brothers of Ahaziah" at Beth-Eked of the shepherds. Beth-Eked is an otherwise unknown location though $2 \mathrm{Kgs} 10$ places it along the route from Jezreel to Samaria, meaning that a large group of Judahite princes were present in Israel following the death of their king Ahaziah at Jehu's hands. It is impossible to say whether they were in Israel for diplomatic or military purposes (see Quine, "Jehu's Slaughter," 537-548; contra Hobbs, 2 Kings, 128, who repoints לשלם to indicate military intent) but if the passage reflects a historical event then Jehu may have killed some of the male candidates for the Judahite kingship. Increasingly, modern scholars do not accept the claim of $2 \mathrm{Kgs}$ 11:1-3 that Athaliah seized the throne by slaughtering all other claimants, either because she may have needed a male heir to rule as regent, or because the length of her reign (six years) indicates that she had internal support, which seems unlikely if the reports of slaughter are accurate; see, e.g., Sergi, "Queenship," 105-109; Kuloba, “Athaliah," 148-150; Park, 2 Kings, 146-148.

${ }^{11}$ Atkinson, Hasmonean State, 85-86 suggests that, contra Sievers ("Role of Women," 135), the earlier mentioned Salina Alexandra, wife of Aristobulus I, was a different person, as no text mentions a new marriage between Alexandra and Jannaeus after Aristobulus I's death. See also Geiger, "Hasmoneans," 4-6. On the matter of fact presentation of Alexandra's succession in War see Liebowitz, "Female Monarchal Succession," 31 .

${ }^{12}$ Liebowitz, “Ambivalent Attitude," 182-183, suggests that the deathbed narrative attempts to explain away this strange succession as Jannaeus' choice. 
elements in the nation (Ant. 13.401-404). ${ }^{13}$ The scene then shifts to Jannaeus' additional deathbed instructions. It is unclear whether this was an attempt by Josephus to literarily limit Alexandra's power, or, a propagandistic interpolation covering up her seizure of power. The matter of how Alexandra deals with her sons - the male candidates for the throne - also differs in War and Antiquities. In War 1.109, she appoints the elder son Hyrcanus II high

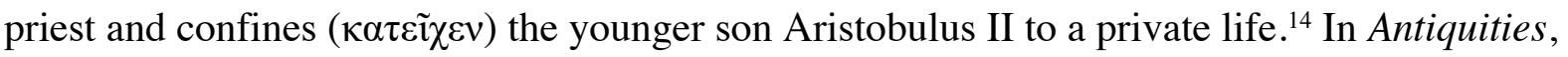
however, Hyrcanus is made high priest with the specific notice that he was too incompetent to rule (Ant. 13.407) and nothing is stated about any confinement or private life of

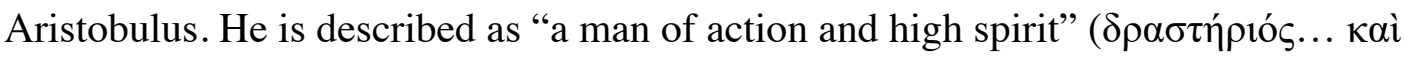
$\theta \alpha \rho \sigma \alpha \lambda \varepsilon \dot{\delta} \varsigma$, Ant. 13.407) and is absent from events until he appears agitating for the royal power in Ant. 13.411 before being sent away with the army (Ant. 13.418). If there was any hint of questionable activity surrounding Alexandra's ascension in War - particularly with a view to Aristobulus - it is absent from the later Antiquities.

Kenneth Atkinson suggests that, at least in Antiquities, "Alexandra assumed a position of political authority" prior to Jannaeus' death. ${ }^{15}$ Indeed, throughout prior history, queens had often played a role in the succession processes of kingdoms, assisting the transition of one king to the next as they themselves moved from being consorts to queen mothers. ${ }^{16}$ She was not the only Hasmonean woman to occupy a position of power and political authority; previously, Hyrcanus I's wife was executed by her son Aristobulus I, as she was evidently perceived to be a threat (Ant. 13.302; War 1.71). In this account, the unnamed wife of Hyrcanus I is also said to be the "mistress of the realm" ( $x v \varrho i ́ \alpha v \tau \hat{v} v$ ö $\lambda \omega v$ ). In addition, Simon Thassi's wife was an important public figure in her own right and Josephus recontextualised her political importance and subsequent execution into a martyrdom narrative (Ant . 13.228-235; War 1.54-60). ${ }^{17}$ Despite the prominence of other Hasmonean women, however, none had ruled as monarch and Etka Liebowitz suggests that Alexandra's age and widowhood allowed for an "exception" to normal succession conventions. ${ }^{18}$ In this regard, Alexandra is comparable to Athaliah, who was also of mature age and a widow. ${ }^{19}$

\footnotetext{
${ }^{13}$ Baltrusch, "Königin Salome Alexandra," 164, and Sievers, "Role of Women," 136, suggest that this explains both her ascension and connection with the Pharisees.

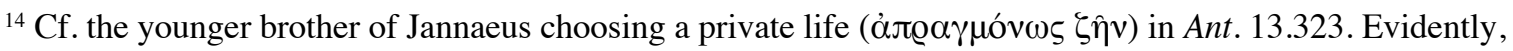
living a "private life" removed one from the sphere of political contention for the throne and if so, then Alexandra confining Aristobulus to a private life may be significant.

${ }^{15}$ Atkinson, Hasmonean State, 138.

16 Thus Ilan, "Queen Salamzion Alexandra," 181-190, concludes that "it was common practice for the king's widow to take an active part in the process of the succession." Similar sentiments can be found in much of the literature pertaining to the biblical queen mothers; e.g., Andreasen, "Role of the Queen Mother," 191-192 and see further Brewer-Boydston, Good Queen Mothers, 3-9. Specifically, with regard to the Hasmonean context, it is worth noting that until Aristobulus I, the Hasmoneans had not held a position of royal power. Previously, their power had been principally located in the high-priesthood - a position which no woman could hold. Kingship was evidently more flexible: at almost the earliest opportunity possible a Hasmonean woman became the monarch.

${ }^{17}$ Contra Geiger, "Hasmoneans," 2-3. See especially Wilker, "Noble Deaths," 72, 85-86, 90-91; Ilan,

"Josephus on Women," 213-214; with reservations, Sievers, "Role of Women," 133-134.

${ }^{18}$ Liebowitz, "Ambivalent Attitude," 184.

${ }^{19}$ Athaliah's age is not specifically stated but her son Ahaziah ascended to the throne when he was twenty-two

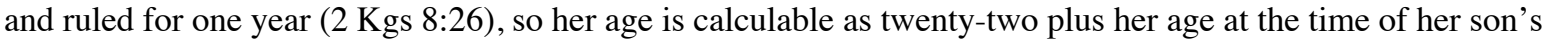
birth, putting her safely in her thirties and possibly older than that. Alexandra was said to be seventy-three at her
} 
גבירה Athaliah was also preceded by at least two significant royal women: Maacah served as for two king's reigns before being deposed for making an image for Asherah (1 Kgs 15:113), and Jezebel was a slightly older contemporary of Athaliah who served as queen consort to Ahab in the northern kingdom of Israel. Jezebel was not a monarch at any point, but the amount of biblical text devoted to her (1 Kgs 16:31-33; 18:1-19; 19; 21; 22:51-52; 2 Kgs 3:1-2; 9:9-10, 22, 30-37) attests to her significance.

In Athaliah and Alexandra we have, therefore, two women of similar trajectories but notable narratological differences. Both women were mature widows who had borne sons and had some previous political influence. Both took the throne in unusual circumstances although, despite the biblical polemic, the historical-political crises surrounding Athaliah's ascension makes her rise to power appear in some ways more normative than Alexandra's, where a woman deliberately replaced potential male heirs. There are thus parallels available between the two, but Josephus does not draw them. Indeed, despite the secrecy and deception surrounding Alexandra's ascension, Athaliah comes off worse in Josephus' writings, portrayed as a foreign murderer abruptly seizing power and threatening the future of the Davidic kingdom (Ant. 9.140). ${ }^{20}$

\section{Spheres of Power: Throne, Military, and Priesthood}

The biblical texts sharply delineate between Athaliah's sphere of power and the priestly sphere of power; she rules (מלכת) from the palace and the priest Jehoiada rules from the temple..$^{21}$ Indeed, Athaliah is so dissociated from the temple that she apparently does not notice her grandson being brought up within its confines, nor the coup being meticulously planned within it (2 Kgs 11:3-12//2 Chr 22:12-23:13). As Patricia Dutcher-Walls observes, those who support the priest Jehoiada's coup are recorded in the texts, while Athaliah is portrayed acting alone..$^{22} 2$ Kings 11 mentions Jehosheba (11:2), the captains $(11: 4,9)$, the guards (11:5-11), and the people of the land (11:14), while 2 Chr names the captains individually (23:1-2) and adds the heads of the families of Israel (23:2) and the Levites (23:4, $7-8)$. In comparison to the show of support Jehoiada amasses for Joash, Athaliah is isolated. Josephus, however, affords her a little more support in his rendering, noting that "she rushed

death in 67 BCE (Ant. 13.430) and she had ruled for nine years, making her around sixty-four when she became queen.

${ }^{20}$ As we have demonstrated elsewhere (Quine and Scales, “Josephus' Adaptation”), Josephus embellishes the opening verses of Athaliah's regnal account quite significantly, stating that she was motivated by the deaths of her son and brother (the Israelite king) Joram to annihilate the royal Davidic house and exterminate all possible descendants. The mention of Joram further emphasises her foreignness to Judah which is also increased through an inclusio referencing Ahab (Ant.9.140, 9.154). Josephus also highlights the house of David-implying that her opposition to it reflected her opposition to Yhwh.

${ }^{21}$ Dutcher-Walls, Narrative Art, 113-127, 148-166. As has been widely noted, the biblical texts undermine Athaliah's reign by not giving her the traditional regnal formulae and ascribing her six year reign to the amount of years Joash hid in the temple, but they still use the feminine participle form of מלך to describe her rule; the same root used of male kings.

22 The same is true of Jehu's coup, which mentions those who support him and lists in detail those who do not, whom he ultimately kills or has killed; Dutcher-Walls, "Athaliah," 188-189. 


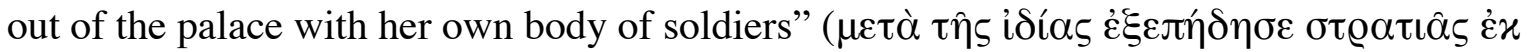

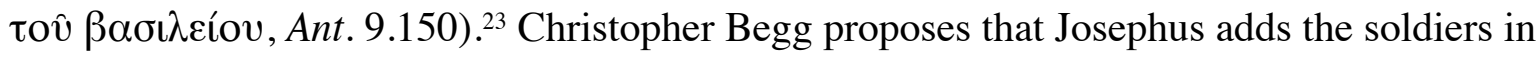
Antiquities to resolve the less believable isolation of Athaliah in the biblical texts. ${ }^{24} \mathrm{We}$ contend, however, that Athaliah's isolation in the biblical texts make the account of her overthrow more believable, for if she had soldiers, the author would have had to account for their lack of action (as Josephus had to do in Ant. 9.146). Josephus' interpolation thus actually creates a problem in the narrative which he has to subsequently resolve. It seems likely that Josephus was accustomed to royal women being associated with military forces (especially Alexandra) and this other knowledge influenced his addition of soldiers to Athaliah's account. ${ }^{25}$

In any case, if serving as monarch of Judah and ruling in Jerusalem entailed any ritual or cultic aspects, the biblical texts do not mention it with regards to Athaliah. Indeed, matters of cult generally revolve around the men connected with her rather than anything she did herself. Thus, for example, Jehu is anointed by a prophet (2 Kgs 9:1-12), shows zeal for Yhwh (2 Kgs 9:22; 10:16-17), destroys the temple of Baal (2 Kgs 10:18-28) and is rewarded by Yhwh ( 2 Kgs 10:30). The lives of Joash and Jehoiada, meanwhile, are dominated by temple matters (on Joash see 2 Kgs 11:3-4, 14; 12:2,4-18), and even the destruction of the temple of Baal is aimed at the (male) priest Mattan (2 Kgs 11:18). ${ }^{26}$ Athaliah is not explicitly connected with the Baal temple in the biblical texts or indeed with worship of Baal or any other deity- here too she appears isolated, even from the divine..$^{27}$ Once again, however, Josephus goes beyond the biblical texts and claims that "Othlia and her husband Joram had constructed [the Baal temple] as an outrage against the ancestral God and in honor of

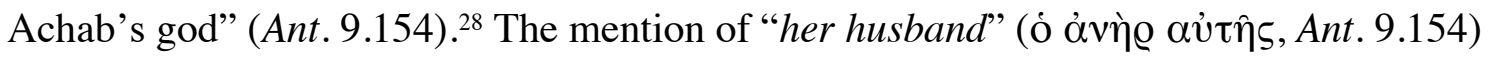
parallels Jezebel's influence on Ahab leading to the construction of the Baal temple in Samaria (1 Kgs 16:32). To summarise, the biblical texts say Athaliah "was ruling (מלכת) over Judah" but mention nothing at all about the administration of the kingdom during her six-year reign and present her as isolated from all forms of support and cultic matters.

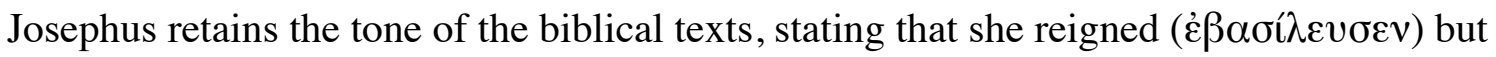

\footnotetext{
${ }^{23}$ Translation from Begg and Spilsbury, Flavius Josephus, 161.

${ }^{24}$ Begg, Later Monarchy, 178 n.77.

${ }^{25}$ The troops may also help explain how Athaliah remained in power for six years. That said, Josephus was clearly interested in Alexandra's military support and mentioning her connection with military forces at multiple junctures. He reports that she was successful in recruiting a mercenary army (Ant. 13.409; War 1.112), she sent an army to Damascus (Ant. 13.418; War 1.115) and states to the elders and Hyrcanus that they had resources available to defend against Aristobulus (Ant. 13.428-429). In comparison, Athaliah's troops are only mentioned in the context of the coup against her and are not connected to the rest of her reign.

${ }^{26}$ The only explicit cultic connection of Athaliah in the biblical texts is indirect: after her death, 2 Chr 24:7 blames the lack of action from the Levites retrospectively on "the children of Athaliah, that wicked woman" who had broken into the temple and used the things of Yhwh for the Baals. Notably, the cultic actions decried here are done by Athaliah's children, not Athaliah herself, and the statement that her children - the princes/princesses of Judah - "broke into" the temple is evidently polemical.

27 This is noteworthy because Jezebel is hyperbolically intertwined with the cultic sins of the northern kingdom (e.g., 1 Kgs 16:31-32; 18:4, 13, 19; 19:1-2; 21:22-23, 25-26; 22:52-53; 2 Kgs 3:1-2; 9:22) and the closest prominent queen mother of Judah prior to Athaliah was Maacah, who was associated with making an image for Asherah (1 Kgs 15:13). The absence of cultic accusations against Athaliah is therefore quite striking.

${ }^{28}$ Begg and Spilsbury, Josephus, 162.
} 
embellishes his version so that Athaliah appears with soldiers at her back and as inherently involved in the construction of the Baal temple.

It is fair to say that Josephus presents a clear view of Athaliah. He acknowledges that she ruled Judah but presents her as a dangerous foreigner intent on wiping out the Davidic royal family (Ant. 9.140-142) and as diametrically opposed to Yhwh. ${ }^{29}$ When it comes to Alexandra, however, he is much more ambivalent and the language he uses to describe the kind of power she held changes between War and Antiquities..$^{30}$ Initially, Josephus appears reluctant to credit Alexandra with any royal power. While he records that Jannaeus gave to her this kingdom ( $\beta \alpha \sigma i \lambda \varepsilon i ́ \alpha v$, War 1.107), he says only that she grasped power

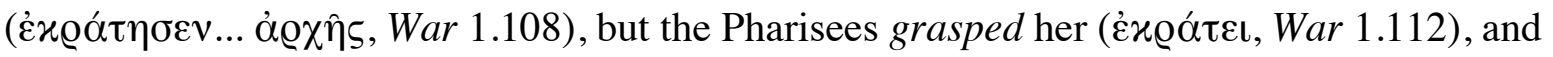

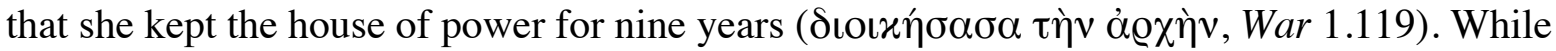
this language makes clear her important role, she is never described as a queen. Her son

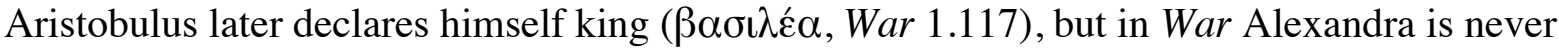
explicitly permitted to occupy this role. Liebowitz suggests that this choice may indicate that Josephus did not consider Alexandra a "real monarch but rather just an administrator." ${ }^{11}$ Yet, in Antiquities, Josephus repeatedly acknowledges her queenship ( $\beta \alpha \sigma \iota \lambda \varepsilon i ́ \alpha \varsigma$, Ant. 13.409; $\beta \alpha \sigma i ́ \lambda$ ı $\sigma \alpha v$, Ant. 13.410, 419, 422, 425, 428 cf. 13.414, 430), though he also states that she was ruled by the Pharisees (Ant. 13.401, 405, 408-410, 423) and that she had an "unreasonable love of power"(Ant. 13.417 cf. 13.430-431).

In contrast to the biblical portrayals of Athaliah, Alexandra is shown to have the support of the military and of another influential party, the Pharisees. ${ }^{32}$ As noted above, Josephus repeatedly mentions Alexandra's military connections and, in many ways, Alexandra exemplified Hellenistic modes of kingship which centred on the monarch's capability in warfare ${ }^{33}$ Her initial action upon Alexander's death was to seize a fortress (Ant. 13.405) and she is further credited with raising a capable military force and ordering campaigns against other Hellenistic kingdoms and city-states (Ant. 13.409, 418, 429; War $1.112,115)$. We might presume then, that she was a strong queen, yet the mention of the Pharisees complicates matters as Josephus claims that they were not only political supporters, but the real power behind Alexandra's reign. ${ }^{34}$ In addition, Josephus claims in War that Alexandra listened to the Pharisees because she was pious, but in Antiquities the suggestion

\footnotetext{
${ }^{29}$ Begg, Later Monarchy, 168 n.6, notes that Josephus uses $\dot{\varepsilon} \xi \alpha \phi \alpha v i ́ \sigma \alpha u$ for both Athaliah's destruction of the house of David, paralleling an earlier instance in Antiquities 9.96 where Yhwh promised never to exterminate the house of David. Athaliah also built the Baal temple (Ant. 9.154).

${ }^{30}$ Liebowitz, "Ambivalent Attitude," 187-188, suggests that the relatively positive portrayal of Alexandra in War was written before Josephus had become accustomed to Roman views towards women and power, particularly military power. By the time Josephus came to write Antiquities, he had adjusted his views and then provided a more negative assessment of Alexandra. While this explains some of the features present in Antiquities, it fails to account for the stronger language Josephus used to convey Alexandra's very real hold on royal power. Josephus includes more negative elements of Alexandra's reign in his Antiquities but more freely employs royal titles here than in War. Thus, Liebowitz suggestion that Josephus grew more accustomed to Roman views cannot fully account for the differences between the two narratives.

${ }^{31}$ Liebowitz, "Ambivalent Attitude," 192.

${ }^{32}$ Lambers-Petry, "Shelomzion," 72. We might also add that she appears to have the support of the people; her popularity is mentioned by Jannaeus as a reason for her suitability for monarchal rule in War 1.107-108.

${ }^{33}$ Liebowitz, "Female Monarchal Succession," 34.

${ }^{34}$ Atkinson, Hasmonean State, 136.
} 
that she join forces with them comes from Jannaeus as part of his deathbed wishes. ${ }^{35}$ These portrayals notably contrast with that of Athaliah, whose influence over her husband is noted in the biblical texts (2 Kgs 8:18, 26-27//2 Chr 21:6; 22:3) but amplified by Josephus and connected with the construction of the Baal temple (Ant. 9.156). Josephus elsewhere suggests that the women of Herod's court were ruled by the Pharisees (Ant. 17.41). ${ }^{36}$ This was not a flattering thing to claim about either party as, for the Pharisees, "rule over women alone is a sign of softness and weakness" and for the women, the Pharisees' rule over them was an encroachment on their husbands' authority. ${ }^{37}$ As Tal Ilan argues, it seems likely that the critiques found in Josephus and other writings are aimed at women who chose to follow Pharisaism. ${ }^{38}$ In this light it is interesting that - despite her husband's opposition to the Pharisees - it was during Alexandra's reign that the Pharisees were reported to have gained significant political influence. If Ilan is correct in identifying female choice as part of the issue with Pharisaism, then in the earlier War, Josephus locates that choice with Alexandra but in the later Antiquities he detracts from her choice by presenting it as Jannaeus' wishes. ${ }^{39}$ Quite why aristocratic women were attracted to Pharisaism is unclear, but for our purposes it is interesting to observe that beyond the appointment of Hyrcanus as high priest and her relationship with the Pharisees, Alexandra is not directly associated with any cultic or religious activities. Although she was apparently pious, as a woman she could not hold power within the priesthood and other religious matters in the same way as a male ruler could, and it is thus not surprising to see that a religious group sympathetic to her policies rose to prominence during her reign.

In terms of their actions during their reigns, Athaliah and Alexandra are difficult to compare due to the differing authorial presentations. In the biblical texts, Athaliah is portrayed as a lone wolf, seizing the throne with no support and nothing of her actions during her reign are mentioned. Josephus embellishes these accounts slightly, affording her some military support and attributing her a role in the construction of the Baal temple, but events during her reign remain undeveloped. Alexandra's reign is given more attention in Josephus, particularly in her relationship with the military and the Pharisees but, again, details of the actual administration of the kingdom under her rule are lacking. Interestingly, despite his claims of her idolatry and increased foreign associations, Josephus seems more comfortable in acknowledging the fact that Athaliah ruled. Even by the writing of Antiquities, at which point Josephus described the reign of Alexandra in royal language, he still limited her by ascribing her authority to the influence of men, particularly Jannaeus and the Pharisees. We suggest that the concept of a foreign enemy seizing the throne made it easier for Josephus to portray Athaliah as a ruler, whereas his view that the non-foreign Alexandra was a good and

\footnotetext{
${ }^{35}$ Ilan, "Aristocratic Women," 11-13.

${ }^{36}$ Ilan, "Aristocratic Women," 6.

${ }^{37}$ Ilan, "Aristocratic Women," 6.

${ }^{38}$ Ilan, "Josephus on Women," 219.

${ }^{39}$ It seems that Liebowitz is correct in labelling Josephus ambivalent about women in power: in War, Alexandra is never called a queen, but her piety leads her to choose to work with the Pharisees. In Antiquities, she is a queen, but her decisions are influenced by her husband's deathbed wishes.
} 
pious woman created tension with the fact that she somehow ended up on the throne despite the existence of two male heirs..$^{40}$

\section{A Queen's Ending: Coups and Critique}

Only a few verses mention Athaliah becoming queen in the biblical texts and Josephus; the majority of material is otherwise centred around the coup that led to her assassination and replacement. Jehoiada's coup has been discussed in detail elsewhere and we need not repeat everything here, but a few points are noteworthy ${ }_{.}^{41}$ First, the coup against her is entirely ideologically framed: a male king replaces a female one, the priest of Yhwh triumphs over the priest of Baal, and the sinful monarchy is righted. ${ }^{42}$ Second, a few details in the coup reports suggest that Athaliah did have some support and the coup had to act swiftly and efficiently to replace her without starting a civil war. For example, secrecy abounds in the early stages (2 Kgs 11:4; 2 Chr 23:1-4; amplified in Jehoiada's explicit statements in Ant. 9.143-145), Jehoiada commands that "any who follow her" should be put to death (2 Kgs 11:15//2 Chr 23:14), and Josephus presents her with an armed force (Ant. 9.150). Third, the assassination of Athaliah and the replacement of her with a male heir is presented as a reestablishment of order over chaos: a Judahite replaces a foreigner, a man replaces a woman, and the Judahite monarchy is realigned with the temple cult. ${ }^{43}$

Whereas Athaliah's son predeceased her, the conspirator against Alexandra was her own son Aristobulus who she "confined to a private life" following the death of his father Jannaeus (War 1.109). This seems to imply that he was kept out of political affairs, yet Aristobulus later appears to advocate on behalf of the enemies of the Pharisees before Alexandra (War 1.114). Once Alexandra falls ill, Aristobulus and his followers managed to capture some military strongholds, recruit an army and he proclaims himself king (War 1.117). Alexandra responds by taking his wife and children hostage (War 1.118) but dies before she could take further action (War 1.119). Aristobulus thus appears to take the opportunity presented by his mother's illness to secure power for himself. ${ }^{44}$ In Antiquities, however, Aristobulus is not said to have been confined to a private life and he appears more active, and generally as more of an agitator against his mother's reign than in War. His

\footnotetext{
${ }^{40}$ Alternatively, the prominence of the Hasmonean family even during the $1^{\text {st }}$ century CE may have resulted in Josephus being more cautious. As Athaliah was a far earlier $9^{\text {th }}$ century ruler, Josephus may have had less interest in giving her the benefit of the doubt.

${ }^{41}$ E.g., Bench, Coup of Jehoiada, 31-73, 192-194; Barré, Rhetoric of Political Persuasion, 86-98, 120-123.

${ }^{42}$ On ideology in this portrayal see especially Dutcher-Walls, "Athaliah"; Narrative Art; Kuloba, "Athaliah."

${ }^{43}$ This is particularly interesting with a view to gender, as Athaliah - being a woman in the male role of kingship - blurred the boundaries between masculinity and femininity, which the biblical authors were evidently uncomfortable with. Jezebel and Athaliah, in particular, are both portrayed as very masculine figures in 1-2 Kings and both are replaced by very masculine men; see, e.g., Macwilliam, "Athaliah," 69-85; Lipka, "Queen Jezebel's Masculinity," 125-150. Guest ("Modelling the Transgender Gaze," 45-80) describes in details Jehu's hyper-masculinity (58-68) and, with the exception of one verse in $2 \mathrm{Kgs} \mathrm{11:2,} \mathrm{Joash} \mathrm{is} \mathrm{always} \mathrm{surrounded} \mathrm{by}$ men, and he sits on the throne of kings (2 Kgs 11:19).

${ }^{44}$ Baltrusch, "Königin Salome Alexandra," 176.
} 
feelings towards his mother's reign are also more plainly stated; "[he] let it be plainly seen that if only he should get the opportunity, he would not leave his mother any power at all" (Ant. 13.411 cf. 13.416). Despite his frustrations, Aristobulus is sent by Alexandra with her army to Damascus, though he fails to achieve much while there (Ant. 13.418). Once Alexandra falls ill, Aristobulus begins an uprising, by slipping away to a fortress ran by some of his father's supporters (Ant. $13.422 \mathrm{cf}$. 13.416-417). His aim was apparently to prevent the Pharisees from seizing power through their control of Hyrcanus (Ant . 13.423). Alexandra, at least initially, did not suspect him of planning a "revolt" ( $\varepsilon \varepsilon \omega \tau \varepsilon \varrho \iota \sigma \mu \hat{\omega})^{45}$ but soon realised that he was gathering a large base of support. In response, she and "her people" place Aristobulus' wife and children into custody in the fortress above the Jerusalem Temple (Ant. 13.425-426). We are then told that, within 15 days, Aristobulus had "occupied twenty-two fortresses, and obtaining resources from these, he gathered an army from Lebanon, Trachonitis and the local princes" (Ant. 13.427). In the face of this dire situation, Alexandra counsels Hyrcanus and the elders of the Jews. Her advice is that they should follow their initiative, although her statement that there is "a nation in a sound condition, an army, and money in the various treasuries" (Ant. 13.429) suggests that she believed they could go to war with Aristobulus. In both accounts, it thus appears that once Alexandra fell ill, Aristobulus seized the opportunity to press his claim for the kingship and did so via a military uprising against his mother, who died before any final outcome.

Josephus maintains the biblical outlook on Athaliah's reign, viewing it as a dangerous interruption in Jewish history and, like the biblical texts, presents her death as the restoration of order. His comments at the end of Alexandra's reign are not quite so derogatory but he does strongly critique Alexandra's "lust for power" and those who let her reign (Ant. 13.430 432). Daniel Schwartz argues that this is part of Josephus' critique of the last Hasmonean rulers, including Alexandra, and the fraternal issues between Hyrcanus and Aristobulus. ${ }^{46}$ Schwartz views Josephus' critique to be directed at the "legitimate rulers of the Jews" more so than Alexandra herself - if the legitimate rulers had ruled properly she would not have come into power. ${ }^{47}$ Liebowitz takes a different view, however, noting Josephus statement that "she [Alexandra] had a lust for these things which were not befitting for a woman," which suggests that Alexandra's gender is central to Josephus' critique. ${ }^{48}$ It is unclear whether Josephus himself was solely responsible for these views or whether he was influenced by his sources, especially Nicolaus of Damascus. ${ }^{49}$ For our purposes, however, it is noteworthy that Alexandra - like Athaliah - was a female monarch whom Josephus viewed as an illegitimate ruler, at least in part because of her gender, yet there are almost no literary echoes or

\footnotetext{
${ }^{45}$ Ant. 13.425. Josephus uses this term elsewhere to describe a cultic innovation (Ant. 5.101), a regime change (Ant. 8.203; 19.327), a city rebelling (Ant. 17.289; War 5.152), and people revolting (Ant. 17.314; 20.106, 113; War 6.343; 7.447; Life 17, 23, 56).

${ }^{46}$ Schwartz, "Josephus on Hyrcanus II," 219-220.

${ }^{47}$ Schwartz, “Josephus on Hyrcanus II," 220.

${ }^{48}$ Liebowitz, "Ambivalent Attitude," 195.

${ }^{49}$ E.g., Schwartz, "Josephus and Nicolaus,” 157-171, views Josephus' portrayal of the Pharisees as the product of Nicolaus and Ilan agrees, viewing Josephus' negative portrayals of women as deriving from Nicolaus; Ilan, "Josephus and Nicolaus." Liebowitz, "Ambivalent Attitude" disagrees, however, arguing that Josephus as an author was responsible in some sense for creating the material he passed on.
} 
allusions to be found between the two in his writings. Even though both queens' reigns ended with coups, death and critique, they remain distinct.

\section{Implications: Reading Queens in Josephus' Writings}

Throughout this analysis, it seems apparent that there are two levels of potential comparison between Athaliah and Alexandra. There are numerous 'historical' similarities between the two figures, which is unsurprising as they were the only two women to have ruled over Judah/Judaea. They were both older women who had been prominent before being widowed, and both factors may have enabled their rise to power. They also took power despite other living claimants, though there was seemingly no male heir of age when Athaliah ruled. Neither woman was greatly involved with cultic matters, though whether this was a reflection of the androcentric cults of the time or a reflection of male authors not wishing to write about female cultic activity is not clear. Finally, both women faced political challenges from male successors and their reigns ended in the midst of coups against them.

On a literary level, the situation is more complex. Josephus was clearly uncomfortable with both queens as women who ruled over men. Yet, while he retains - and embellishes the biblical texts' negative view of Athaliah, Josephus affords Alexandra a mixed legacy. ${ }^{50}$ While she presided over a time of peace and prosperity for Judaea (Ant. 13.432) and he notes that she was pious and popular (War 1.107-108), Josephus viewed it as "unbecoming" $(\mu \grave{\eta}$ $\pi \rho \circ \sigma \eta \kappa o ́ v \tau \omega v$, Ant. 13.431) for her to have ruled as a woman, and glossed over her reign with some marginal comments..$^{51}$ Josephus' portrayal of Athaliah is more straightforwardly negative, yet the majority of the polemic is directed at her character and her actions rather than her office. Whereas Josephus appears ambivalent with his acknowledgement of Alexandra's royal status in War and Antiquities, Athaliah unquestionably rules as a queen. Betsy Halpern-Amaru argues that Josephus created typologies of a number of biblical women, including a category of villainesses, usually presented as seductive temptresses..$^{52}$ Yet, despite his critique at various points of both women, neither Athaliah or Alexandra fit this category; they do not use their sexuality to further their interests. Moreover, although

\footnotetext{
${ }^{50}$ As noted above, in Antiquities Josephus added more elements of conflict to the Alexandra narrative, and embellished elements which amplified both positive and negative traits of her character.

${ }^{51}$ The kings before and after Alexandra were much more indicative of the decline of the Hasmonean household, and, especially in his War narrative, created a clear narrative flow towards ever increasing tensions in Judaea. See Baltrusch, "Königin Salome Alexandra," 172.

${ }^{52}$ Halpern-Amaru, "Portraits," 153-155. Not all scholars agree with Halpern-Amaru's typologies, but Swart, "Rahab and Esther," 63-64, suggests that Josephus streamlined the biblical narratives of Rahab and Esther, although his motives for doing so are unclear. Schroeder also argues that Josephus reframes the character of Deborah by diminishing her role and having her more closely follow conventional Greco-Roman standards of womanhood; Schroeder, Deborah's Daughters, 7-9, and cf. Feldman, "Hellenizations," 143. However, this understanding of Greco-Roman standards for womanhood may be reductionist. Ilan points out that Josephus' misogynistic elements do not have to be Hellenistic adaptations, but rather evidence that the women in many "biblical narratives act self-confidently, behave in unconventional ways, and thereby create ethical and religious dilemmas for interpreters hundreds of years later"; Ilan, "Flavius Josephus," 185.
} 
Athaliah was foreign to Judah, she is not portrayed in the manner of Potiphar's wife or the Midianite women - the foreign villainesses. Athaliah and Alexandra are also interesting when viewed through the lens of gender and royal power, as they do not conform to the stereotype of royal motherhood wherein consorts provided heirs and queen mothers guided their sons. Both women are reported to have killed or passed over male heirs in order to take power for themselves and by ruling in the place of men, they blur the boundaries between gender and role. ${ }^{53}$ Their queenships thus present a serious threat to an androcentric concept of kingship, yet Josephus does not compare them in any way. As his portrayal of Athaliah is highly negative, on the one hand, it seems likely that he did not want to draw parallels that might reflect negatively on Alexandra. On the other hand, he was clearly ambivalent about her title, character, and reign. The only case where literary interpolation may have occurred is where Josephus adds information about Athaliah's command of soldiers, although this may also be simply a general association of a monarch with armed forces. In any case, the lack of literary connections creates the perception that Athaliah and Alexandra's reigns were incomparable anomalies, and this perception has been perpetuated in scholarship. The tendency to avoid discussing Athaliah's reign in detail as a point of comparison for Alexandra's reign further reinforces the marginality of queenship and accepts too easily the portrayal of the authors. Rather than simply stating that Athaliah was not a model for Josephus' portrayal of Alexandra, we contend that we should ask why she was not a model - why Josephus isolated these two queens in his reception of their reigns and what this means for his view of Alexandra.

\footnotetext{
${ }^{53}$ See further Quine, "Bereaved Mothers."
} 
Andreasen, Niels-Erik A. "The Role of the Queen Mother in Israelite Society." CBQ 45.2 (1983): 179-194.

Atkinson, Kenneth. A History of the Hasmonean State: Josephus and Beyond. Jewish and Christian Texts. London: Bloomsbury, 2016.

Baltrusch, Ernst. "Königin Salome Alexandra (76-67 v. Chr.) und die Verfassung des hasmonäischen Staates." Historia 50.2 (2001): 163-179.

Barré, Lloyd M. The Rhetoric of Political Persuasion: The Narrative Artistry and Political Intentions of 2 Kings 9-11. CBQMS 20. Washington: Catholic Biblical Association of America, 1988.

Begg, Christopher. Josephus' Story of the Later Monarchy (AJ 9,1-10,185). Leuven: Peeters, 2000.

Begg, Christopher, and Paul Spilsbury. Flavius Josephus - Translation and Commentary: Vol. 5. Judean Antiquities 8-10. Leiden: Brill, 2005.

Bench, Clayton. The Coup of Jehoiada and the Fall of Athaliah: The Discourses and Textual Production of 2 Kings 11. Gorgias Dissertations 65. Piscataway, NJ: Gorgias Press, 2016.

Brewer-Boydston, Ginny. Good Queen Mothers, Bad Queen Mothers: The Theological Presentation of the Queen Mother in 1-2 Kings. CBQMS 54; Washington: Catholic Biblical Association of America, 2016.

Dutcher-Walls, Patricia. "Athaliah: The Queen who Was Not." Pages 182-198 in Characters and Characterization in the Book of Kings. Edited by Keith Bodner and Benjamin J.M. Johnson. London: Bloomsbury, 2020.

Dutcher-Walls, Patricia. Narrative Art, Political Rhetoric: The Case of Athaliah and Joash. JSOTSup 209. Sheffield: Sheffield Academic Press, 1996.

Feldman, Louis H. "Hellenizations in Josephus' Version of Esther.” TAPA 101 (1970): 143-170.

Geiger, Joseph. “The Hasmoneans and Hellenistic Succession.” JJS 53.1 (2002): 1-17.

Guest, Deryn. "Modelling the Transgender Gaze: Performances of Masculinities in 2 Kings 9-10." Pages 45-80 in Transgender, Intersex and Biblical Interpretation. Edited by Teresa J. Hornsby and Deryn Guest. Atlanta, GA: SBL Press, 2016.

Halpern-Amaru, Betsy. "Portraits of Biblical Women in Josephus' Antiquities." JJS 39.2 (1988): 143-170.

Hobbs, T.R. 2 Kings. WBC 13; Waco, TX: Word Books, 1985.

Ilan, Tal. "The Attraction of Aristocratic Women to Pharisaism during the Second Temple Period." HTR 88.1 (1995): 1-33.

Ilan, Tal. "Flavius Josephus and Biblical Women.” Pages 167-185 in Apocrypha Early Jewish Writings. Edited by Eileen Schuller and Marie-Theres Wacker. The Bible and Women: An Encyclopedia of Exegesis and Cultural History 3.1. Atlanta, GA: SBL, 2017. 
Ilan, Tal. "Josephus and Nicholaus on Women." Pages 221-262 in Geschichte - Tradition Reflexion: Festschrift für Martin Hengel zum 70. Geburtstag. Edited by Hubert Cancik, Hermann Lichtenberger and Peter Schäfer. Vol. 1. Tübingen: Mohr Siebeck, 1996.

Ilan, Tal. "Josephus on Women." Pages 210-221 in A Companion to Josephus. Edited by Honora Howell Chapman and Zuleika Rodgers. New York: John Wiley \& Sons, 2016.

Ilan, Tal. “Queen Salamzion Alexandra and Judas Aristobulus I's Widow.” JSJ 24.2 (1993): 181190.

Ilan, Tal. "Shelamzion in Qumran: New Insights." Pages 57-68 in Historical Perspectives: From the Hasmoneans to Bar Kokhba in Light of the Dead Sea Scrolls. Proceedings of the Fourth International Symposium of the Orion Center, 27-31 January 1999. Edited by David Goodblatt, Avital Pinnick and Daniel R. Schwartz. STDJ 37. Leiden; Brill, 2001.

Ilan, Tal. Silencing the Queen: The Literary Histories of Shelamzion and Other Jewish Women. TSAJ 115. Tübingen: Mohr Siebeck, 2006.

Josephus. Translated by Henry St. J. Thackeray et al. 10 vols. LCL. Cambridge, MA: Harvard University Press, 1926-1965.

Kuloba, Robert W. "Athaliah of Judah (2 Kings 11): A Political Anomaly or an Ideological Victim?" Pages 139-152 in Looking Through a Glass Bible: Postdisciplinary Biblical Interpretations from the Glasgow School. Edited by A.K.M. Adam and Samuel Tongue. BibInt 125. Leiden: Brill, 2014.

Lambers-Petry, Doris. "Shelomzion ha-malka: The Hasmonean Queen and her Enigmatic Portrayal by Josephus." Pages 63-77 in Internationales Josephus-Kolloquium Dortmund 2002: Arbeiten aus dem Institutum Judaicum Delitzschianum. Edited by Jürgen U. Kalms and Folker Siegert. Münster: LIT, 2003.

Liebowitz, Etka. "Esther and Alexandra: Paradigms of Queenship in the Septuagint and in Josephus' Writings." Lectio Difficilior 1 (2012):

http://www.lectio.unibe.ch/12_1/liebowitz_esther_and_alexandra.htm.

Liebowitz, Etka. "Female Monarchal Succession in Hellenistic and Jewish Society in Antiquity: Parallels and Contrasts." JSJ 49.1 (2018): 30-48.

Liebowitz, Etka. “Josephus's Ambivalent Attitude towards Women and Power: The Case of Queen Alexandra." JAJ 6.2 (2015): 182-205.

Lipka, Hilary. “Queen Jezebel's Masculinity.” Pages 125-150 in Biblical Masculinities Anew. Edited by Ovidiu Creangă. Sheffield: Sheffield Phoenix Press, 2019.

Macwilliam, Stuart. “Athaliah: A Case of Illicit Masculinity." Pages 69-85 in Biblical Masculinities Foregrounded. Edited by Ovidiu Creangă and Peter-Ben Smit. Hebrew Bible Monographs 62. Sheffield: Sheffield Phoenix Press, 2017.

Mullen Jr., E. Theodore. Narrative History and Ethnic Boundaries: The Deuteronomistic Historian and the Creation of Israelite National Identity. SemeiaSt 24. Atlanta, GA: Scholars Press, 1993. 
Park, Song-Mi Suzie. 2 Kings. Wisdom Commentary; Collegeville, MN: Liturgical Press, 2019.

Quine, Cat. "Bereaved Mothers and Masculine Queens: The Political Use of Maternal Grief in 1-2 Kings." Open Theology: Special Issue on Women and Gender in the Bible and Biblical World 6 (2020): 407-422.

Quine, Cat. "Jehu's Slaughter of Judah's Royal Family at Beth-Eked (2 Kings 10:13-14): A Closer Look.” ZAW 131.4 (2019): 537-548.

Quine, Cat, and Joseph Scales. “Josephus’ Adaptation of the Athaliah Narratives.” VT (forthcoming).

Schroeder, Joy A. Deborah's Daughters: Gender Politics and Biblical Interpretation. Oxford: Oxford University Press, 2014.

Schwartz, Daniel R. "Josephus on Hyrcanus II." Pages 210-232 in Josephus and the History of the Greco-Roman Period: Essays in Memory of Morton Smith. Edited by Fausto Parente and Joseph Sievers. Leiden: Brill, 1994.

Schwartz, Daniel R. “Josephus and Nicolaus on the Pharisees.” JSJ 14.2 (1983): 157-171.

Sergi, Omer. "Queenship in Judah Revisited: Athaliah and the Davidic Dynasty in Historical Perspective." Pages 99-111 in Tabou et transgressions. Actes du colloque organisé par le Collège de France, Paris, les 11-12 avril 2012. Edited by J.-M. Durand, M. Guichard and T. Römer. OBO 274. Göttingen: Vandenhoeck \& Ruprecht, 2015.

Sievers, Joseph. "The Role of Women in the Hasmonean Dynasty." Pages 132-146 in Josephus, the Bible, and History. Edited by Louis H. Feldman and Gohei Hata. Detroit, IL: Wayne State University Press, 1989.

Swart, G.J. "Rahab and Esther in Josephus - An Intertextual Approach.” Acta Patristica et Byzantina 17 (2006): 50-65.

Wilker, Julia. "Noble Deaths and Dynasty: A Popular Tradition from the Hasmonean Period in Josephus." JSJ 48.1 (2017): 69-91. 